\title{
Beata Bieszk-Stolorz ${ }^{*}$, Iwona Markowicz,** \\ UNEMPLOYMENT DURATION TABLES
}

\begin{abstract}
The purpose of the article is to construct the registered unemployment duration table. The table is a non-parametric model (also called a tabular model) showing the duration of a given phenomenon. In demography it is most often used as a life (or mortality) table. We will construct the cohort tables on the basis of individual data provided by the Poviat Labour Office in Szczecin. The cohort will consist of unemployed individuals registered in 2012 and observed by the end of 2013. The event regarded as the one ending the unemployment spell will be the moment of an individual's de-registration from the PLO due to finding employment. The remaining data have been considered censored. One of the elements of the table is hazard intensity. We will compare the intensities of unemployment exits in the cohort subgroups.
\end{abstract}

Keywords: duration tables, hazard intensity, unemployment.

JEL: C1, C4, J6.

\section{INTRODUCTION}

The feature characteristic of the labour market in Szczecin is that it has been strongly imbalanced for years. The research shows that during the period of workforce shortage in Poland, Szczecin belonged to cities with the largest number of job vacancies per one jobseeker, while at the time of workforce surplus the local unemployment rate was one of the highest in the country (Kopycińska 2005; Bieszk-Stolorz 2013). In 2000-2013 the dynamics of the unemployment rate in Szczecin was similar to the national and regional one, which is shown in Figure 1.

At the end of December 2012 and 2013 the unemployment rate in Szczecin reached $11 \%$ and $10.6 \%$, respectively, making it the third (2012) and the fourth (2013) of the largest Polish cities. Presently, the unemployment rate in the Zachodniopomorskie voivodeship is one of the highest in Poland. Predominantly, the regions observing the most difficult situation in this aspect are the ones where in the communist times the state owned farms used to play a considerable role in agricultural industry, as well as those with strong traditional industries (e.g. shipyards) which did not receive adequate government's

\footnotetext{
* Institute of Econometrics and Statistics, University of Szczecin, beatus@ wneiz.pl

** Institute of Econometrics and Statistics, University of Szczecin, iwona.markowicz@ wneiz.pl
} 
attention in the period of economic transformation (Kwiatkowski, Tokarski 2007). The Zachodniopomorskie voivodeship meets both these conditions.

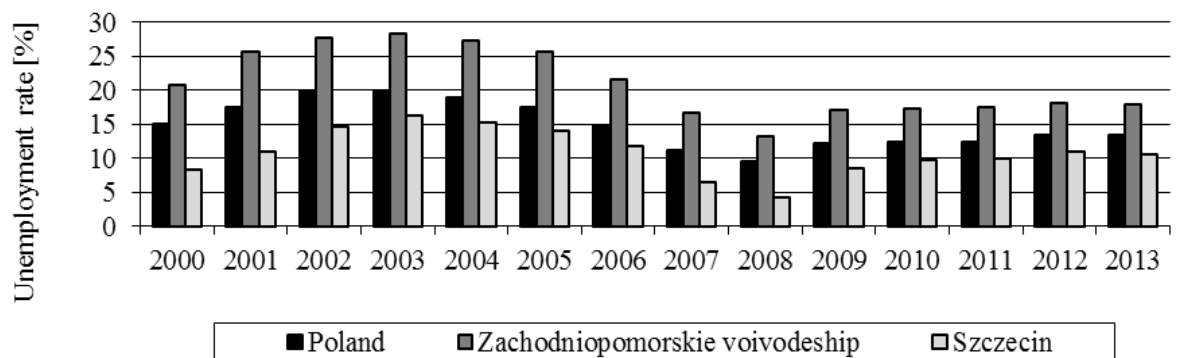

Figure 1. The registered unemployment rate in Poland, Zachodniopomorskie voivodeship and Szczecin in 2000-2013 (\%)

Source: own study based on data GUS and Poviat Labour Office in Szczecin.

The purpose of this paper is to construct the tables of survival in registered unemployment. The main focus is on one element of the tables, i.e. the intensity of unemployment leaving. The application of a nonparametric survival model allowed for comparing the intensity in gender and age groups. As a variety of studies show, gender is an important determinant of the labour market activity (Rynek pracy... 2014). Taking into consideration young people's difficult situation on this market, the authors divided the sample into two age groups: up to 25 and $25+$.

In the case of young people in Europe, participation in education and in the labour market interact in complex ways, going beyond a straightforward, oneway transition from school to work. In some countries, young people start working much earlier than in others, e.g. in the form of summer jobs or jobs for students. It is also possible to be in education and on the labour market at the same time, leading to an overlap. In parallel to a decrease in the proportion of young people in education, there is an increase in those on the labour market, employed or unemployed. The pace of exit from education is not identical to the pace of entry onto the labour market, as some people are in education and on the labour market at the same time, while others move out of education and stay outside the labour market. There are significant structural differences among European countries in young people's participation in the labour market. The reason is a combination of institutional factors (e.g. formal apprenticeship schemes), cultural determinants, whether there is a job market for students, the role of professional training, etc. Differences in the national systems of education and training also play a major role (Eurostat 2015). 


\section{STATISTICAL DATA}

The study was based on individual data from the Poviat Labour Office in Szczecin. The cohort consists of 21,398 unemployed registered in 2012 and observed by the end of 2013. The final event that ended the episode was deregistration due to finding employment. The remaining data were considered censored - other deregistration reasons or the end of observation. The cohort was divided according to gender and age. A special focus was put on the situation of young jobseekers. Therefore, the observed individuals were split into two age groups; up to 25 and $25+$. The sizes of the subgroups are presented in Table 1.

Table 1. Size of the observed population

\begin{tabular}{|l|c|c|}
\hline \multicolumn{1}{|c|}{ Removed } & Number of people & Work \\
\hline Total & 21398 & 8559 \\
\hline Female & 9868 & 4345 \\
\hline Male & 11530 & 4214 \\
\hline Bellow age 25 & 1940 & 703 \\
\hline 25 and more & 19458 & 7856 \\
\hline Female bellow age 25 & 949 & 391 \\
\hline Female 25 and more & 8919 & 3954 \\
\hline Male bellow age 25 & 991 & 312 \\
\hline Male 25 and more & 10539 & 3902 \\
\hline
\end{tabular}

Source: own study.

\section{THE REGISTERED UNEMPLOYMENT DURATION TABLES AND INTENSITY OF DEREGISTRATION}

The survival analysis employs parametric, semiparametric and nonparametric models. The construction of parametric models involves the adoption of a theoretical distribution of the observed variable (Gazińska 2003; Frątczak, GachCiepiela, Babiker 2005). When the subject of a study is to show how long the unemployed individual remains registered, it is difficult to adopt a concrete distribution. In such instance nonparametric models are applied, the example of which are survival tables (Markowicz 2012) or semiparametric models (Bieszk-Stolorz, Markowicz 2012). The survival tables are a tabular model, most frequently used in demography as life expectancy tables. In other fields of science they are used to study the duration of phenomena (Gołata 1994, Gazińska, Mojsiewicz 2004). 
In this study a monthly interval has been adopted for cohort tables. The observed cohort consists of the unemployed registered by the Poviat Labour Office in Szczecin in 2012. The cohort tables represent the findings of the cohort observation until it was left by all its members or until the observation was terminated. The observation ended on 31 December 2013, which means that the censored units were included into consideration.

The cohort tables present the process of changes occurring over time in the cohort's composition. The cohort tables belong to models with continuous time, but estimates of functions presented here are discrete, which is why the value of the time variable, grouped in equal intervals, was given as the beginning of the interval $(t)$. The number of the unemployed that survived $\left(n_{t}\right)$ was given at the beginning of the interval and calculated as $n_{t+1}=n_{t}-\left(z_{t}+c_{t}\right)$, wherein $n_{t}$ for $t=0$ $\left(n_{0}\right)$ denotes the initial number of the unemployed in the cohort; $z_{t}$ marks the number of the unemployed unregistered in the interval $\langle t, t+1), c_{t}$ denotes the number of unemployed who did not experience that event by the end of the cohort observation time.

The next two values in the cohort table of survival were estimated according to the discrete approach because they can be calculated only for the f time interval. The probability of unregistered in the time interval $f_{t}$, defined as the conditional probability of unregistered in the interval of survival time $\langle t, t+1)$, providing that the firm has not been liquidated by the time $t$.

The distribution of the duration of unemployment cannot be assigned to any known type of probability distribution. This is why the functions describing the process of the unemployment duration are not known, and the tables of survival contain their estimates calculated on the basis on empirical data. The probability estimator of deregistration in the time interval $\hat{f}_{t}$ is a ratio of the number of people deregistered in a given time interval $\left(z_{t}\right)$ to the number of people who survived by the beginning of the interval $\left(n_{t}\right)$.

The probability of survival $S_{t}$ and the intensity of deregistration $h_{t}$ are functions that are continuous by nature. In the tables they are shown in discrete formulation. The survival probability $S_{t}$ determined for the interval $\langle t, t+1)$ means the likelihood that the unemployed individual will be deregistered after the time $t+1$. The estimator of the survival probability function $\hat{S}_{t}$ is the rate of the number of the unemployed who survived in unemployment by the time $t+1$ to the initial size of the cohort (Markowicz 2012).

The estimator of the intensity function $\hat{h}_{t}$ is determined as a relationship of the estimator of deregistration probability in the interval $\langle t, t+1)$ to half the sum of 
the survival probability estimators for the intervals $\langle t, t+1)$ and $\langle t-1, t)$ (Balicki 2006):

$$
\hat{h}_{t}=\frac{\hat{f}_{t}}{\left(\hat{S}_{t}+\hat{S}_{t-1}\right) / 2}
$$

The table of survival in registered unemployment built for the whole cohort under observation is shown in Table 2.

Table 2. The table of survival in registered unemployment for cohort (total)

\begin{tabular}{|c|c|c|c|c|c|c|}
\hline $\begin{array}{l}\text { Duration } \\
\text { time } \\
\text { [months] } \\
\text { beginning } \\
\text { of the } \\
\text { interval }\end{array}$ & $\begin{array}{c}\text { Number of } \\
\text { unemployed, } \\
\text { whoendured }\end{array}$ & $\begin{array}{l}\text { Number of } \\
\text { unemployed } \\
\text { unregistered } \\
\text { in section of } \\
\text { time }\end{array}$ & $\begin{array}{c}\text { Number of } \\
\text { censored } \\
\text { unemployed } \\
\text { in section of } \\
\text { time }\end{array}$ & $\begin{array}{l}\text { The } \\
\text { probability } \\
\text { of } \\
\text { unregistered } \\
\text { in section of } \\
\text { time }\end{array}$ & $\begin{array}{l}\text { The } \\
\text { probability } \\
\text { of not } \\
\text { taking up } \\
\text { employment }\end{array}$ & $\begin{array}{l}\text { The intensity } \\
\text { of } \\
\text { deregistration } \\
\text { to work }\end{array}$ \\
\hline \multirow[t]{2}{*}{$t$} & $n_{t}$ & $z_{t}$ & $c_{t}$ & $f_{t}$ & $S_{t}$ & $h_{t}$ \\
\hline & & & & & 1.0000 & \\
\hline 0 & 21398 & 1914 & 2032 & 0.0895 & 0.9106 & 0.0936 \\
\hline 1 & 17452 & 1233 & 606 & 0.0707 & 0.8529 & 0.0801 \\
\hline 2 & 15613 & 1003 & 987 & 0.0642 & 0.8061 & 0.0775 \\
\hline 3 & 13623 & 702 & 979 & 0.0515 & 0.7733 & 0.0653 \\
\hline 4 & 11942 & 600 & 570 & 0.0502 & 0.7452 & 0.0662 \\
\hline 5 & 10772 & 482 & 523 & 0.0448 & 0.7227 & 0.0610 \\
\hline 6 & 9767 & 440 & 689 & 0.0451 & 0.7021 & 0.0632 \\
\hline 7 & 8638 & 403 & 513 & 0.0467 & 0.6833 & 0.0674 \\
\hline 8 & 7722 & 298 & 424 & 0.0386 & 0.6694 & 0.0571 \\
\hline 9 & 7000 & 249 & 402 & 0.0356 & 0.6577 & 0.0536 \\
\hline 10 & 6349 & 216 & 352 & 0.0340 & 0.6476 & 0.0521 \\
\hline 11 & 5781 & 197 & 259 & 0.0341 & 0.6384 & 0.0530 \\
\hline 12 & 5325 & 184 & 579 & 0.0346 & 0.6298 & 0.0545 \\
\hline 13 & 4562 & 149 & 568 & 0.0327 & 0.6229 & 0.0522 \\
\hline 14 & 3845 & 122 & 528 & 0.0317 & 0.6172 & 0.0512 \\
\hline 15 & 3195 & 90 & 424 & 0.0282 & 0.6130 & 0.0458 \\
\hline 16 & 2681 & 74 & 415 & 0.0276 & 0.6095 & 0.0452 \\
\hline 17 & 2192 & 67 & 306 & 0.0306 & 0.6064 & 0.0503 \\
\hline 18 & 1819 & 46 & 289 & 0.0253 & 0.6042 & 0.0418 \\
\hline 19 & 1484 & 39 & 283 & 0.0263 & 0.6024 & 0.0436 \\
\hline 20 & 1162 & 29 & 281 & 0.0250 & 0.6010 & 0.0415 \\
\hline 21 & 852 & 13 & 264 & 0.0153 & 0.6004 & 0.0254 \\
\hline 22 & 575 & 8 & 289 & 0.0139 & 0.6001 & 0.0232 \\
\hline 23 & 278 & 1 & 277 & 0.0036 & 0.6000 & 0.0060 \\
\hline
\end{tabular}

Source: own study. 
The values in the last column indicate the intensity of deregistration $h_{t}$ due to finding a new job decreases with the unemployment duration. The highest intensity is observed at the beginning of the unemployment spell. The trend is also seen in the accelerated decrease in the values of the probability of failure in job seeking $S_{t}$. For example, 3 months following registration this probability is 0.81 , which means that $19 \%$ of the observed jobseekers found employment in that period of time. A year after registration $36 \%$ of them left unemployment, but after two years the number was merely $40 \%$.

The tables of survival in unemployment have been also constructed for individual subgroups of the unemployed. The most important element of these tables, i.e. the intensity of deregistration due to unemployment exit, is shown in Figures 2-5. The intensity of unemployment exits in the group of up to 25-year olds differed from both the group of 25+ and the cohort in total (Figure 2). Despite clear fluctuations, this intensity is higher in the group of younger people. Their average intensity reached 0.0643 , while in the older group it equalled 0.0523 (total 0.0529). As far as the gender perspective was concerned, the unemployment exits among women (mean 0.0592) were more intensive than among men (mean 0.0475) (Figure 3). That was true in the case of the older group as well (Figure 4). In the group of less than 25-year olds the intensity of exits in the first six months of their unemployment spell was stronger among women, while in the case of men it did not increase until they had entered the long-term unemployment (0.1061, for men 0.0777). Figure 5 shows the comparison of the unemployment exits among women and men in both age groups. The intensity of exits among both younger and older women was the same (0.0649 and 0.0587 , respectively). In the case of men the intensity was higher in the younger group (0.0661 and 0.0469 , respectively).
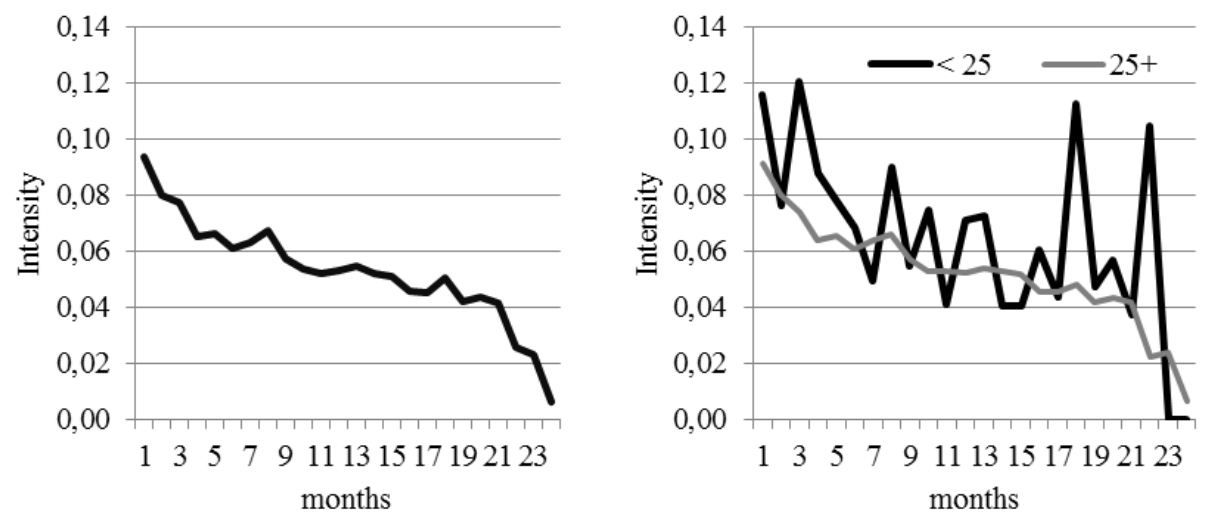

Figure 2. Intensity of deregistration to work for unemployed total and in age groups

Source: own study. 


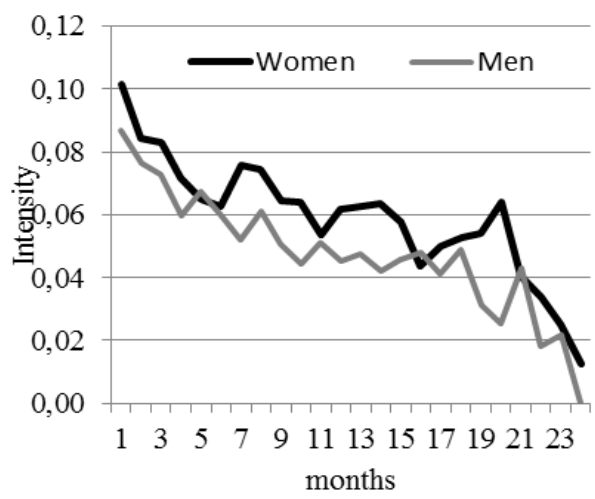

Figure 3. Intensity of deregistration to work for unemployed by sex

Source: own study.

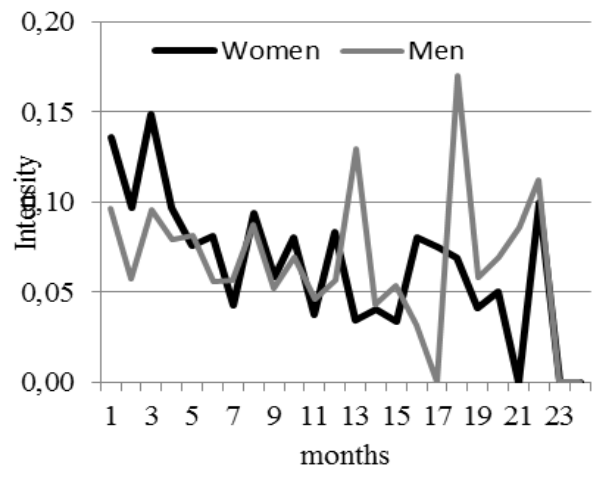

age: $<25$

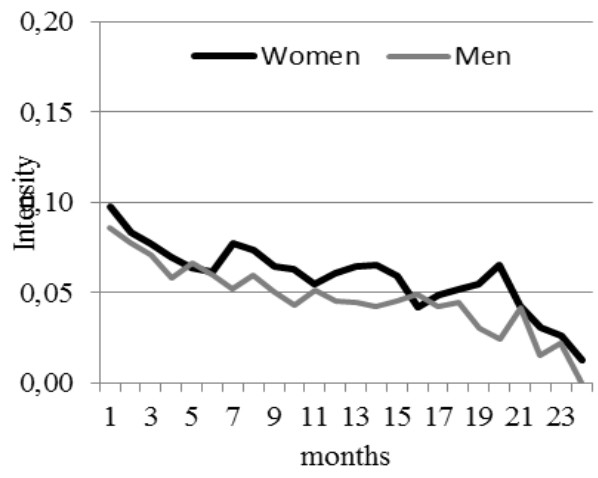

age: $25+$

Figure 4. Intensity of deregistration to work for unemployed in age groups by sex Source: own study.

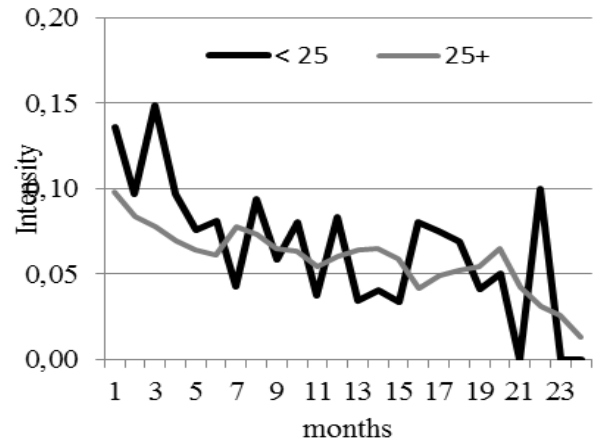

women

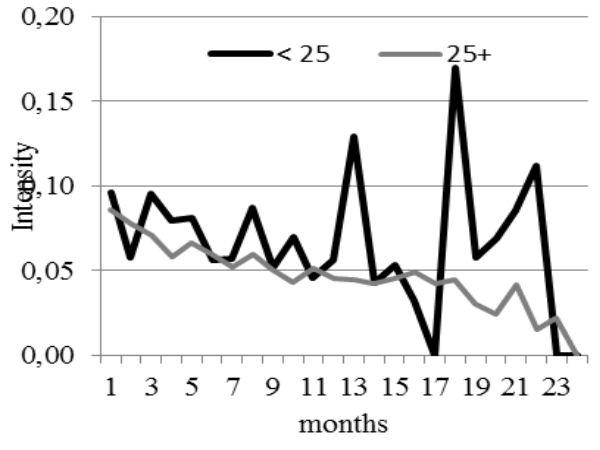

men

Figure 5. Intensity of deregistration to work for unemployed women and men by age groups Source: own study. 


\section{CONCLUSIONS}

In the study the survival tables are used, as they are considered a nonparametric model. As such it is particularly useful when the function of the time distribution of a phenomenon under study is not known, as it happens in the studies on the duration of unemployment spells. Some elements of the table of survival in unemployment have a specific cognitive value, such as the survival probability (survival function) and the intensity of deregistration events due to unemployment exits (hazard function). The former of these functions represents the pattern of objects' exits from the cohort throughout the lifetime of a given phenomenon. The latter indicates the fluctuations in the intensity of that phenomenon in fixed periods of time. The study results show that the average intensity of unemployment exits was stronger for the young and for women.

\section{REFERENCES}

Balicki A. (2006), Analiza przeżycia i tablice wymieralności, PWE, Warszawa.

Bieszk-Stolorz B. (2013), Analiza historii zdarzeń w badaniu bezrobocia, Wydawnictwo volumina.pl, Szczecin.

Bieszk-Stolorz B., Markowicz I. (2012), Modele regresji Coxa $w$ analizie bezrobocia, CeDeWu, Warszawa.

Cox D.R. (1972), Regression Models and Life-Tables, "Journal of the Royal Statistical Society. Series B (Methodological)", vol. 34, no. 2.

Eurostat (2015), Participation of young people in education and the labour market, Statistics Explained, http://ec.europa.eu.

Frątczak E., Gach-Ciepiela U., Babiker H. (2005), Analiza historii zdarzeń. Elementy teorii, wybrane przyklady zastosowań, SGH, Warszawa.

Gazińska M. (2003), Potencjal demograficzny w regionie. Analiza ilościowa, Wydawnictwo Naukowe Uniwersytetu Szczecińskiego, Szczecin.

Gazińska M., Mojsiewicz M. (2004), Nieparametryczne modele trwania życia - budowa i przykłady zastosowań, „Zeszyty Naukowe Uniwersytetu Szczecińskiego”, nr 394, s. 87-100.

Gołata E. (1994), Tablice aktywności zawodowej ludności - kwestie metodologiczne, „Wiadomości Statystyczne", nr 3.

Kopycińska D. (2005), Nierównowaga na rynku pracy a postawy pracownicze, [w:] D. Kopycińska (red.), Konkurencyjność rynku pracy i jego podmiotów, Katedra Mikroekonomii Uniwersytetu Szczecińskiego, Szczecin, s. 183-196.

Kwiatkowski E., Tokarski T. (2007), Bezrobocie regionalne $w$ Polsce $w$ latach 1995-2005, „Ekonomista”, nr 4, s. 439-455.

Markowicz I. (2012), Statystyczna analiza żywotności firm, Wydawnictwo Naukowe Uniwersytetu Szczecińskiego, Szczecin.

Rynek pracy i wykluczenie społeczne w kontekście percepcji Polaków. Diagnoza społeczna 2013, (2014), Raport tematyczny, I.E. Kotowska (red.), MPiPS i Centrum Rozwoju Zasobów Ludzkich. 
Beata Bieszk-Stolorz, Iwona Markowicz

\section{TABLICE TRWANIA W BEZROBOCIU}

Streszczenie. Celem artykułu jest konstrukcja tablic trwania w bezrobociu rejestrowanym. Jest to model nieparametryczny czasu trwania określonego zjawiska (nazywany tabelarycznym). Najczęściej jest stosowany w demografii jako tablice trwania życia (wymieralności). Tablice kohortowe zostaną skonstruowane w oparciu o dane indywidualne z Powiatowego Urzędu Pracy w Szczecinie. Kohortą są osoby bezrobotne zarejestrowane w 2012 roku i obserwowane do końca 2013 roku. Zdarzeniem kończącym epizod jest wyrejestrowanie $\mathrm{z}$ powodu podjęcia pracy. Pozostałe dane przyjęto za cenzurowane. Jednym z elementów tablicy trwania jest intensywność hazardu. Intensywności wychodzenia z bezrobocia zostaną porównane w podgrupach kohorty.

Słowa kluczowe: tablice trwania, intensywność hazardu, bezrobocie.

JEL: C1, C4, J6. 